\title{
Al-Chizan
}

Jurnal Pemikiran Hukum Islam

ISSN 1907-0985, E ISSN 2442-8256

Vol. 13, No. 2, 2017, h. 204-226

DOI: https://doi.org/10.30603/am.v13i2.854

\section{Mediation Optimization in Gorontalo Religion Court}

\author{
Sri Wahyuni Husain
}

Pascasarjana IAIN Sultan Amai Gorontalo

Email: wahyunithuwyhayhu@gmail.com

Abstract: This study aims to determine the optimization of the implementation of mediation in the Gorontalo Religious Court. This research is a field research with data collection methods in the form of observations, interviews and documentation. Data's were analyzed using qualitative descriptive. The results of the study found that the implementation of mediation in the Gorontalo Religious Court was not yet fully optimal. Based on the cases decided by the Gorontalo Religious Court in 2016 totaling 1524 and entering the mediation process as many as 87 cases and only 1 case that was successfully mediated (0.1\%). Factor failure of the mediation process because the mediation room facilities are still not efficient enough, because the parties to queue, even some mediator judges carry out mediation in the judge's room itself, there is no certified mediator as explained in the Minister of Religion Regulation (PERMA) Number 1 of 2016 about Procedure for Mediation at Court.

Keywords: Mediation, Religious Court, Gorontalo

\section{Optimalisasi Mediasi di Pengadilan Agama Gorontalo}

Abstrak: Penelitian ini bertujuan untuk mengetahui optimalisasi pelaksanaan mediasi di Pengadilan Agama Gorontalo. Penelitian ini adalah penelitian lapangan dengan metode pengumpulan data berupa pengamatan, wawancara dan dokumentasi. Data dianalisis dengan menggunakan deskriptif kualitatif. Hasil penelitian menemukan bahwa pelaksanaan mediasi di Pengadilan Agama Gorontalo belumlah optimal secara keseluruhan. Berdasarkan kasus yang diputus oleh Pengadilan Agama Gorontalo tahun 2016 sebanyak 1524 dan masuk proses mediasi sebanyak 87 perkara dan hanya 1 perkara yang berhasil dimediasi $(0,1 \%)$. Faktor gagalnya proses mediasi dikarenakan fasilitas ruangan mediasi masih belum cukup efisien, menyebabkan para pihak mengantri, bahkan ada beberapa hakim mediator melaksanakan mediasi di ruangan hakim itu sendiri, belum adanya mediator yang bersertifikat sebagaimana yang diterangkan dalam Peraturan Menteri Agama (PERMA) Nomor 1 Tahun 2016 tentang Prosedur Mediasi di Pengadilan.

Kata Kunci: Mediasi, Pengadilan Agama, Gorontalo 


\section{A. Pendahuluan}

Dalam negara hukum yang tunduk kepada the rule of law, kedudukan peradilan dianggap sebagai pelaksana kekuasaan kehakiman yang berperan sebagai katup penekan atas segala pelanggaraan hukum dan ketertiban masyarakat. Peradilan dapat dimaknai juga sebagai tempat terakhir mencari kebenaran dan keadilaan, sehingga secara teoritis masih diandalkan sebagai badan yang berfungsi dan berperan menengakkan kebenaran dan keadilan ( $t o$ enforce the truth and judtice). ${ }^{1}$

Pada dasarnya dalam penyelesaian sengketa alternatif kita mengenal adanya mediasi. Penyelesaian sengketa melalui proses perundingan atau mufakat para pihak dengan dibantu oleh mediator yang tidak memiliki kewenangan memutus atau memaksakan sebuah penyelesaian. Ciri utama proses mediasi adalah perundingan yang esensinya sama dengan proses musyawarah atau konsensus. Sesuai dengan hakikat perundingan atau musyawarah, maka tidak boleh ada paksaan untuk menerima atau menolak sesuatu gagasan atau penyelesaian selama proses mediasi berlangsung. Segala sesuatunya harus memperoleh persetujuan dari para pihak.

Berbagai fakta telah menunjukkan bahwa pada dasarnya mediasi bukan merupakan suatu metode yang asing dalam upaya penyelesaian sengketa di tengah masyarakat, hanya saja konteks pendekatan dan caranya yang berbeda yang lebih disesuaikan dengan budaya hukum setempat. Hal tersebut dapat dilihat dimana dalam masyarakat Indonesia mediasi merupakan kebudayaan bangsa Indonesia sendiri, baik dalam masyarakat tradisionl maupun sebagai dasar Negara Pancasila dikenal dengan istilah musyawarah untuk mufakat.

Secara umum mediasi dapat diartikan upaya penyelesaian sengketa para pihak dengan kesepakatan bersama melalui mediator yang bersikap netral dan tidak membuat keputusan atau kesimpulan bagi para pihak tetapi menunjang fasilitator untuk terlaksananya dialog antara pihak dengan suasana keterbukaan, kejujuran dan tukar pendapat untuk tercapaiya mufakat. ${ }^{2}$

${ }^{1}$ M. Yahya Harahap, Hukum Acara Perdata: Tentang Gugatan, Persidangan, Penyitaan, Pembuktian, dan Putusan Pengadilan (Cet. VII; Jakarta: Sinar Grafika, 2008), 229.

${ }^{2}$ Susanti Adi Nugroho, Mediasi Sebagai Alternatif Penyelesaian Sengketa (Cet. I; Jakarta: Telaga Ilmu, 2009), 25. 
Sri Wahyuni Husain

Untuk mengatasi problematika sistem peradilan yang belum optimal dan efesien, maka muncul alternatif penyelesaian sengketa dengan perdamaian. Dalam hukum acara di Indonesia didapati dalam Pasal 130 Herziene Inlandsch Reglegment (HIR) maupun Pasal 154 Rechtsreglement Voor De Buitengewesten (R.Bg). Kedua pasal dimaksud menghendaki penyelesaian sengketa melalui cara damai.

Pasal 130 ayat (1) HIR berbunyi:

(1) Jika pada hari yang ditentukan itu, kedua bela pihak datang, maka pengadilan negeri mencoba dengan perantara ketuanya akan memperdamaikan.

(2) Jika perdamaian yang demikian itu terjadi, maka tentang hal itu pada waktu bersidang, diperbuat sebuah akte, dengan nama kedua bela pihak diwajibkan untuk mencukupi perjanjian yang diperbuat itu; maka surat (akte) itu akan berkekuatan dan akan dilakukan sebagai putusan hakim yang biasa. ${ }^{3}$

Landasan formil mengenai integritas mediasi dalam sistem peradilan pada dasarnya bertitik tolak dari ketentuan Pasal 130 HIR, Pasal 145 R.Bg, namun untuk lebih memberdayakan dan mengefektifkannya Mahkamah Agung memodifikasinya ke arah yang lebih bersifat memaksa compulsory. ${ }^{4}$ Oleh karena itu lahirlah Surat Edaran (SEMA) pada tanggal 30 Januari 2002 yang berjudul Pemberdayaan Pengadilan Tingkat Pertama Menerapkan Lembaga Damai, namun SEMA tersebut dapat dikatakan tidak berhasil karena pada hakekatnya hakim bukan mediator yang baik dan ada keengganan hakim melakukan proses mediasi karena keadaan itu mendorong Mahkamah Agung untuk menerbitkan Peraturan Mahkamah Agung (PERMA) Nomor 2 Tahun 2003 tanggal 11 September 2003 tentang Prosedur Mediasi di Pengadilan.

Setelah dilakukannya evaluasi terhadap pelaksanaan prosedur mediasi di pengadilan berdasarkan PERMA Nomor 2 Tahun 2003 ternyata ditemukan beberapa permasalahan yang bersumber dari Peraturan Mahkamah Agung tersebut, sehingga PERMA Nomor 2 Tahun 2013 direvisi dengan maksud untuk lebih mendayagunakan mediasi yang terkait dengan proses berperkara di Pengadilan. Dalam Peraturan Mahkamah Agung Republik Indonesia Nomor 1 Tahun 2008 tentang Prosedur Mediasi di

\footnotetext{
${ }^{3}$ R. Tresna, Komentar HIR (Cet. XVIII; Jakarta: Pradnya Paramita, 2005), 110.

${ }^{4}$ M. Yahya Harahap, Hukum Acara Perdata, 242.
} 
Optimalisasi Mediasi di Pengadilan Agama Gorontalo

Pengadilan belumlah optimal memenuhi kebutuhan pelaksanaan mediasi yang lebih berdayaguna dan mampu meningkatkan keberhasilan mediasi di Pengadilan. Oleh karenanya, Mahkamah Agung mengeluarkan peraturan baru yaitu, Peraturan Mahkamah Agung (PERMA) Nomor 1 Tahun 2016 tentang Prosedur Mediasi di Pengadilan. Sejak Lahirnya PERMA tersebut maka pengintegrasian mediasi sebagai alternatif penyelesaian sengketa dalam hukum acara peradilan mulai diberlakukan seperti yang tertuang dalam konsideran PERMA Nomor 1 Tahun 2016 disebutkan:

a. Bahwa mediasi merupakan salah satu proses penyelesaian sengketa secara damai yang tepat, efektif, dan dapat membuka akses yang lebih luas kepada para pihak untuk memperoleh penyelesaian yang memuaskan serta berkeadilan;

b. Bahwa dalam rangka reformasi birokrasi Mahkamah Agung Republik Indonesia yang berorientasi pada visi terwujudnya badan peradilan Indonesia yang agung, salah satu elemen pendukung adalah Mediasi sebagai instrumen untuk meningkatkan akses masyarakat terhadap keadilan sekaligus implementasi asas penyelenggaraan peradilan yang sederhana, cepat, dan biaya ringan;

c. Bahwa ketentuan hukum acara perdata yang berlaku, Pasal 154 Reglemen Hukum Acara untuk Daerah Luar Jawa dan Madura (Reglement Tot Regeling Van Het Rechtsweze In De Gewesten Buiten Java En Madura) dan Pasal 130 Reglemen Indonesia yang diperbaharui (Het Herziene Inlandsh Reglement) mendorong Para pihak untuk menempuh proses perdamaian yang dapat didayagunakan melalui Mediasi dengan mengintegrasikannya ke dalam prosedur berperkara di Pengadilan;

d. Bahwa prosedur mediasi di Pengadilan menjadi bagian hukum acara perdata dapat memperkuat dan mengoptimalkan fungsi lembaga peradilan dalam penyelesaian sengketa;

e. Bahwa peraturan Mahkamah Agung Republik Indonesia Nomor 1 Tahun 2008 tentang Prosedur Mediasi di Pengadilan belum optimal memenuhi kebutuhan pelaksanaan Mediasi yang lebih berdayaguna dan mampu meningkatkan keberhasilan Mediasi di Pengadilan.

Proses mediasi dipandang sebagai cara penyelesaian sengketa yang lebih cepat dan murah dibandingkan dengan proses litigasi. Di Indonesia

\footnotetext{
${ }^{5}$ Mahkamah Agung RI, Peraturan Mahkamah Agung Nomor 01 Tahun 2016 tentang Proses Mediasi di Pengadilan.
} 
Sri Wahyuni Husain

memang belum ada penelitian yang membuktikan asumsi bahwa mediasi merupakan proses yang cepat dan murah dibandingkan proses litigasi. Akan tetapi, jika didasarkan pada logika bahwa suatu perkara apabila diputus, pihak yang kalah seringkali mengajukan upaya hukum dalam tingkat banding maupun kasasi, sehingga membuat penyelesaian atas perkara yang bersangkutan dapat memakan waktu yaang cukup lama, sejak pemeriksaan tingkat kasasi Mahkamah Agung. Sebaliknya, jika perkara dapat diselesaikan dengan perdamain, maka para pihak dengan sendirinya dapat menerima hasil akhir karena merupakan kerja mereka yang mencerminkan kehendak bersama para pihak.

Berdasarkan proses pengintegrasian mediasi ke dalam proses beracara di pengadilan dapat menjadi salah satu instrumen yang cukup efektif dalam mengatasi masalah penumpukan perkara di pengadilan dan juga memperkuat dan memaksimalkan fungsi lembaga non peradilan untuk penyelasian sengketa di samping proses acara pengadilan yang bersifat ajudikatif (memaksa). Didalam suatu persidangan perdata, hakim berkewajiban untuk mendamaikan para pihak yang bersengketa. Kelalaian hakim yang tidak menempuh prosedur mediasi dapat mengakibatkan pemeriksaan perkara tersebut menjadi cacat formil dan putusannya menjadi batal demi hukum.

Ajaran Islam dikenal adanya proses penyelesaian sengketa melalui perdamaian yang disebut dengan al-sulh. Islam menganjurkan pihak yang bersengketa menempuh jalur damai, baik di depan pengadilan maupun di luar pengadilan. Al-sulh memberikan kesempatan para pihak untuk memikirkan jalan terbaik dalam penyelesaian sengketa, dan mereka tidak lagi terpaku secara ketat pada pengajuan alat bukti. Para pihak memperoleh kebebasan mencari jalan keluar agar sengketa dapat diakhiri. Anjuran alQur'an dan Nabi Muhammad saw. dalam ajaran Islam memilih al-sulh dapat memuaskan para pihak dan tidak ada pihak yang merasa menang dan kalah dalam penyelesaian sengketa. ${ }^{6}$

Peradilan Agama sebagai wujud peradilan Islam di Indonesia tentunya mengamalkan konsep al-sulh yang merupakan ajaran agama Islam. ${ }^{7}$

\footnotetext{
${ }^{6}$ Syahrizal Abbas, Mediasi dalam Perspektif Hukum Syariah, Hukum Adat, dan Hukum Nasional (Cet. I; Jakarta: Kencana Prenada Media, 2009), 159-160.

${ }^{7}$ Peradilan Agama merupakan salah satu pelaku kekuasaan kehakiman yang termasuk peradilan khusus bagi umat Islam. Eksistensinya dapat dilihat dari pasal berikut ini: (2) Kekuasaan kehakiman dilakukan oleh Mahkamah Agung dan Badan Peradilan yang
} 
Optimalisasi Mediasi di Pengadilan Agama Gorontalo

Para hakim di Pengadilan Agama harus selalu mengupayakan dua pihak yang bersengketa untuk menempuh jalur damai, karena jalur damai akan mempercepat penyelesaian perkara dan mengakhirinya atas kehendak kedua belah pihak.

Berdasarkan Amandemen Undang-Undang Peradilan Agama (UU RI No. 3 Tahun 2006) dijelaskan tentang tugas dan wewenang Peradilan Agama. Disamping itu PERMA Nomor 1 Tahun 2016 membahas tentang mediasi di Pengadilan Agama.

Khususnya di Pengadilan Agama Gorontalo pemberlakuan PERMA tersebut telah diberlakukan sejak dikeluarkannya pada tanggal 03 Februari 2016. Namun dari beberapa kasus yang masuk di Pengadilan Agama Gorontalo masih didapati tidak terselesaikan memalui jalur mediasi, misalnya pada tahun 2016 pengintegrasian mediasi ke dalam proses beracara di Pengadilan sesuai Peraturan Mahkamah Agung Nomor 01 Tahun 2016 belum mampu mengurangi perkara yang masuk ke persidangan, sehingga pencapaian belum sesuai dengan harapan.

\section{B. Pengertian dan Perkembangan Mediasi}

Secara etimologi istilah mediasi berasal dari bahasa latin "mediare" yang berarti berada di tengah. Makna ini menunjukkan pada peran yang ditampilkan pihak ketiga sebagai mediator dalam menjalankan tugasnya menengahi dan menyelesaikan sengketa antara pihak. "Berada di tengah" juga bermakna mediator harus berada pada posisi netral dan tidak memihak dalam menyelesaiakan sengketa. Dalam Collins English Dictionary and Thesaurus disebutkan bahwa mediasi adalah kegiatan menjembatani antara dua pihak yang bersengketa guna menghasilkan kesepakatan. Sedangkan dalam Kamus Besar Bahasa Indonesia disebutkan bahwa yang dimaksud dengan mediasi adalah proses pengikutsertaan pihak ketiga dalam menyelesaikan suatu perselisihan sebagai penasehat. ${ }^{8}$

Penjelasan mediasi dari sisi kebahasaan (etimologi) di atas lebih menekankan pada keberadaan pihak ketiga dalam hal ini mediator yang

berada di bawahnya dalam lingkungan Peradilan Umum, lingkungan Peradilan Agama, lingkungan Peradilan Militer, lingkungan Peradilan Tata Usaha Negara, dan oleh sebuah Mahkamah Konstitusi. Lihat Republik Indonesia, Undang-Undang Dasar RI Tahun 1945, pasal 24 ayat (2).

${ }^{8}$ Syahrizal Abbas, Mediasi, 2. 
Sri Wahyuni Husain

menjembatani para pihak yang bersengketa untuk dapat menyelesaiakan perselisihan ataupun sengketa yang terjadi dicantara mereka. Sedangkan pengertian mediasi secara terminologi menurut para ahli yaitu:

Menurut Joni Emirzon yang dimaksud:

Mediasi adalah upaya penyelesaian sengketa para pihak dengan kesepakatan bersama melalui mediator yang bersikap netral, dan tidak membuat keputusan atau kesimpulan bagi para pihak dengan suasana keterbukaan, kejujuran dan tukar pendapat untuk tercapainya mufakat."

Menurut Christoper W. Moore mengungkapkan bahwa:

Mediasi adalah intervensi terhadap suatu sengketa atau negosiasi oleh pihak ketiga yang dapat diterima, tidak berpihak, dan netral yang tidak mempunyai kewenangan untuk mengambil keputusan dalam membantu para pihak yang berselisih dengan upaya mencapai kespakatan secara sukarela dalam penyelesaian permasalahan yang disengketakan. ${ }^{10}$

Menurut Faudy mengemukakan bahwa

Mediasi adalah salah satu alternatif dalam menyelesaiakan sengketa. Mediasi adalah proses negosiasi untuk memecahkan masalah melalui pihak luar yang tidak memihak dan netral yang bekerja dengan pihak yang bersengketa untuk membantu menemukan solusi dalam menyelesaiakan sengketa tersebut secara memuaskan bagi kedua belapihak. Pihak ketiga yang membantu menyelesaiakan sengketa tersebut disebut mediator. ${ }^{11}$

Penyelesaian konflik secara damai (mediasi) sudah dipraktekkan dalam kehidupan masyarakat Indonesia berabad-abad yang lalu. Salah satunya yang menjadi falsafah bangsa Indonesia yaitu musyawarah mufakat yang dijelma dalam dasar Negara yaitu Pancasila. Mediasi dengan landasan musyawarah menuju kesepakatan damai mendapat pengaturan tersendiri dalam sejumlah produk hukum Hindia-Belanda maupun dalam produk hukum setelah Indonesia merdeka sampai hari ini.

${ }^{9}$ Joni Emirzon, Alternatif Penyelesaian Sengketa di Luar Pengadilan (Jakarta: Gramedia Pustaka Utama, 2001), 69.

${ }^{10}$ Susanti Adi Nugroho, Mediasi, 69.

${ }^{11}$ Munir Fuady, Arbitras Nasional, Alternatif Penyelesaian Sengketa Bisnis, (Bandung: Citra Aditya Bakti, 2004), 47. 


\section{a. Masa Kolonial Belanda}

Pada masa kolonila Belanda pengaturan penyelesaian sengketa melalui damai lebih banyak ditujukan pada proses damai dilingkungan peradilan, sedangkan penyelesaian sengketa diluar pengadilan, kolonial Belanda lebih cenderung memberikan kesepakatan pada hukum adat. Pada masa kolonial Belanda lembaga peradilan diberikan kesempatan untuk mendamaikan para pihak yang bersengketa. Kewenangan mendamaikan hanya sebatas kasus-kasus keluarga dan perdata pada umumnya. Dalam Pasal 130 HIR Pasal 156 R.Bg atau Pasal 31 Rv (Reglement op de Rechtsvoordering) disebutkan bahwa hakim atau majelis hakim akan mengusahakan perdamaian sebelum perkara mereka diputuskan. Ketentuan dalam Pasal $130 \mathrm{HIR} / 154 \mathrm{Rbg} / 31 \mathrm{Rv}$ menggambarkan bahwa penyelesaian sengketa melalui jalur damai merupakan bagian dari proses penyelesaian sengketa di pengadilan. Upaya damai menjadi kewajiban hakim, dan ia tidak boleh memutuskan perkara sebelum upaya mediasi dilakukan terlebih dahulu. Apabila mediasi berhasil maka hakim harus mengeluarkan akta damai, akta damai memiliki kekuatan hukum sama dengan vonis dari hakim. ${ }^{12}$

Peraturan perundang-undangan pada masa Belanda juga mengatur penylesaian sengketa melalui upaya damai diluar pengadilan. Upaya tersebut dikenal dengan arbitrase. Ketentuan mengenai hal ini diatur dalam Pasal 615-651 Rv (Staatsblad 1874: 52) atau Pasal 337 HIR (Staatsblad 1941: 44) atau Pasal 154 Rbg (Staatsblad 1927: 227) atau Pasal 31 Rv (Staatsblad 1874: 52), ketentuan dari pasal-pasal lain berbunyi: jika bangsa orang bumi putra dan orang Timur Asing hendak menyuruh memutuskan perselisihannya oleh juru pemisah, maka dalam hal ini mereka wajib menurut peraturan mengadili perkara bangsa Eropa. Menurut HIR penyelesaian sengketa melalui arbitrase hanya dapat dilakukan bila memenuhi persyaratan: (1) Para pihak ketika membuat perjanjian menyebutkan bahwa bila terjadi perselisihan dikemudian hari, maka penyelesaian diserahkan kepada arbitrase, (2) Para pihak bersepakat ketika terjadinya perselisihan untuk menyerahkan perkaranya kepada wasit (arbiter) dan tidak mengajukan perkara tersebut kepada hakim pengadilan. ${ }^{13}$

b. Masa Kemerdekaan Sampai Saat ini

Dalam Pasal 4 ayat 20 dan Pasal 5 ayat 2 UU No. 4 Tahun 2004 tentang kekuasaan kehakiman disebutkan peradilan dilakukan dengan

\footnotetext{
${ }^{12}$ Syahrizal Abbas, Mediasi, 289.

${ }^{13}$ Syahrizal Abbas, Mediasi, 290.
} 
Sri Wahyuni Husain

sederhana, cepat dan biaya ringan. Pengadilan membantu pencarian keadilan dan berusaha mengatasi segala hambatan dan rintangan untuk pencapaian peradilan yang sederhana, cepat dan biaya ringan. Penerapan asas cepat dan biaya ringan mengalami kendala dalam praktik peradilan karena banyaknya perkara yang masuk, terbatasnya tenaga hakim, dan minimnya dukungan fasilitas bagi lembaga peradilan tingkat pertama yang wilayah hukumnya meliputi Kabupaten/Kota. Akibat tersendatnya asas ini telah mengakibatkan pencari keadilan mengalami kesulitan guna mendapatkan hak-hak secara cepat. Keadaan ini tentunya akan berdampak buruk pada penegakkan hukum di Indonesia. Menghadapi tantangan yang begitu berat ini system hukum Indonesia memiliki aturan hukum yang dapat digunakan untuk menyelesaikan sengketa secara cepat. Dimana di lingkungan peradilan dapat ditempuh jalur damai melalui proses mediasi sedangkan di luar pengadilan dapat ditempuh jalur arbitrase mediasi, negosiasi atau fasilitasi sebagai bentuk penyelesaian sengketa.

Adapun dasar hukum yang mengatur penyelesaian perkara di luar pengadilan yaitu Undang-Undang Nomor 30 Tahun 1999 dan Peraturan Pemerintah RI Nomor 54 Tahun 2000 tentang Lembaga Penyedia Jasa Pelayanan Sengketa Lingkungan Hidup. Kedua peraturan tersebut hanya mengatur tentang penyelesaian sengketa di luar persidangan yang terdidi dari arbitrase, negosiasi, fasilitasi dan konsultasi. Sedangkan ketentuan mengenai mediasi di pengadilan diatur dalam PERMA RI Nomor 2 Tahun 2003 tentang prosedur mediasi dipengadilan yang telah diperbaharui dengan PERMA RI Nomor 1 Tahun 2008 tentang prosedur mediasi di pengadilan dan telah mendapatkan pembaharuan kembali dengan PERMA RI Nomor 1 Tahun 2016 tentang Mediasi di Pengadilan. PERMA ini menempatkan mediasi sebagai bagian dari proses penyelesaian perkara yang diajukan para pihak ke pengadilan. Pengintegrasian mediasi dalam proses beracara di pengadilan akan dapat mengintenfisikan para pihak menempuh jalur damai dalam penyelesaian sengketa pada tingkat pertama.

\section{Mediasi dalam Konsep Islam dan Hukum Adat}

1. Mediasi dalam Konsep Islam

Al-Qur'an menjelaskan bahwa konflik dan sengketa yang terjadi di kalangan umat manusia adalah suatu realita. Manusia sebagai khalifah di bumi dituntut untuk menyelesaiakn sengketa, karena manusia dibekali akal dan wahyu dalam menata kehidupannya. Manusia harus mencari pola 
penyelesaian sengketa sehingga penegakan keadilan dapat terwujud. Dalam penyelesaian sengketa konsepsi Islam mengusahakan perdamaian seperti terkandung dalam Al-Qur'an bahwa sesungguhnya orang-orang yang beriman adalah bersaudara dan diperintahkan agar senantiasa memperbaiki hubungan persaudaraan tersebut.

\section{Mediasi dalam Konsep Hukum Adat}

Tradisi penyelesaian sengketa dalam hukum adat cenderung menggunakan pola adat atau dalam istilah lain disebut kekeluargaan. Masyarakat hukum adat lebih mengutamakan penyelesaian sengketa melalui jalur musyawarah, yang bertujuan untuk mewujudkan perdamaian dalam masyarakat. Dalam penyelesaian sengketa menggunakan musyawarah, masyarakat hukum adat juga mempraktekkan model penyelesaian sengketa melalui mediasi, negosiasi, fasilitasi dan arbitrase. Para tokoh adat menjalankan fungsinya sebagai mediator, negosiator, faslitator dan arbiter. Dalam prakteknya para tokoh adat umumnya menggunakan pendekatan ini secara bersama-sama, terutama dalam hukum privat maupun publik.

Tokoh adat mendominasi penyelesaian sengketa melalui mediasi dan arbitrase, karena dalam sistem hukum adat tidak membedakan hukum privat dan hukum publik. Penyelesaian sengketa melalui mediasi dan arbitrase dapat dilakukan dalam dua hal langangan hukum ini. Hal ini berbeda dengan sistem hukum yang berlaku di Indonesia yang mana mediasi dan arbitrase hanya digunakan sebagai alternatif penyelesaian sengketa dalam kasus-kasus perdata. Mediasi dan arbitrase tidak dapat diterapkan dalam kasus-kasus pidana. $^{14}$

Keterlibatan tokoh adat dalam penyelesaian sengketa pidana, tidak mengharuskan adanya izin dari pihak keluaga yang bersengketa. Tokoh adat sebagai penjaga stabilitas dan nilai adat dengan sendirinya berkewajiban untuk menyelesaikan sengketa atau kasus pidana. Dalam sengketa hukum privat tokoh adat dapat bertindak atas insiatif sendiri untuk menyelesaikan sengketa, jika dianggap kasus tersebut dapat mengganggu keadilan dan nilai keseimbangan masyarakat adat. Tetapi adakalanya para pihak yang bersengketa yang meminta para tokoh adat untuk menyelesaikan sengketa adat mereka. ${ }^{15}$

\footnotetext{
${ }^{14}$ Syahrizal Abbas, Mediasi, 250.

${ }^{15}$ Syahrizal Abbas, Mediasi, 250-251.
} 
Sri Wahyuni Husain

Kesimpulannya bahwa dalam penyelesaian sengketa yang tejadi dalam masyarakat hukum adat penggunaan mediasi dan arbitrase lebih luas, hal ini terlihat bahwa dalam penggunaan mediasi dan arbitrase tidak hanya digunakan untuk penyelesaian sengketa hukum privat saja tetapi juga digunakan dalam penyelesaian hukum publik. Sebab hukum adat tidak mengenal adanya perbedaan baik itu antara hukum privat maupun hukum publik dimana mereka lebih mengutamakan dan berusaha sekuat mungkin agar masalah yang timbul dalam masyarakat adat dapat terselesaikan dengan cara perdamaian dengan bantuan tokoh adat sebagai penengah.

\section{Peranan Mediator dalam Proses Mediasi}

1. Persyaratan Mediator

Mediator sebagai pihak yang sangat berperan penting dalam membantu para pihak untuk mencari solusi terbaik dalam menyelesaikan sengketa guna mencari kesepakatan perdamaian, maka dalam menjalankan fungsinya ada beberapa persyaratan yang harus dipenuhi, persaratan berupa kemampuan personal mediator:

a. Kemampuan membangun kepercayaan para pihak, merupakan sikap yang harus ditunjukan mediator kepada para pihak bahwa ia tidak memiliki kepentingan apapun terhadap penyelesaian sengketa.

b. Mediator harus menunjukkan sikap empati kepada para pihak, bahwa dirinya memiliki rasa peduli terhadap persengketaan yang mendera kedua belah pihak.

c. Seorang mediator tidak bersikap menghakimi, sebab mediator bukanlah seorang hakim yang dapat memutuskan sengketa berdasarkan fakta-fakta hukum.

d. Memberikan reaksi positif terhadap setiap pernyataan para pihak walaupun pernyataan tersebut tidak diset ujui. ${ }^{16}$

Selain persyaratan di atas adalah persyaratan mediator dalam kaitannya dengan kemampuan interpersonal. Persyaratan ini tidak cukup bagi seseorang untuk menjadi mediator, karena ia harus didukung oleh persyaratan lain yang berkaitan dengan para pihak dan permasalahan yang dipersengketaan oleh mereka, persyaratan lain terdiri atas:

\footnotetext{
${ }^{16}$ Syahrizal Abbas, Mediasi, 56.
} 
Optimalisasi Mediasi di Pengadilan Agama Gorontalo

a. Keberadaan mediator disetujui oleh kedua belah pihak.

b. Tidak mempunyai hubungan keluarga sedarah atau semenda sampai dengan derajat kedua dengan salah satu pihak yang bersengketa.

c. Tidak memiliki hubungan kerja dengan salah satu pihak yang bersengketa.

d. Tidak mempunyai kepentingan financial, atau kepentingan lain terhaddap kesepakatan para pihak.

e. Tidak memiliki kepentinngan terhadap proses perundingan maupun hasilnya. ${ }^{17}$

\section{Peran Mediator}

Mediator memiliki peranan menentukan dalam suatu proses mediasi. Gagal tidaknya mediasi sangat ditentukan oleh peran yang ditampilkan mediator. Dalam memimpin pertemuan yang dihadiri kedua bela pihak, mediator berperan mendampingi, mengarahkan dan membantu para pihak untuk membuka komunikasi positif dua arah, karena lewat komunikasi yang terbangun akan memudahkan proses mediasi selanjutnya. Dalam memandu proses komunikasi, mediator ikut mengarahkan para pihak agar membicarakan secara bertahap upaya yang mungkin ditempuh keduanya dalam rangka mengakhiri sengketa. Mediator ikut memperlancar komunikasi, sehingga para pihak memperoleh pemahaman yang menyeluruh terhadap persoalan yang mereka persengketakan.

Sejumlah peran mediator yang muncul ketika proses mediasi berjalan antara lain:

1. Menumbuhkan dan mempertahankan kepercayaan diri antara para pihak;

2. Menerangkan proses dan mendidik para pihak dalam hal komunikasi dan menguatkan suasana yang baik;

3. Membantu para pihak untuk menghadapi situasi atau kenyataan;

4. Mengajar para pihak dalam proses dan keterampilan tawar menawar dan;

5. Membantu para pihak mengumpulkan informasi penting, dan menciptakan pilihan-pilihan untuk memudahkan penyelesaian problem. $^{18}$

\footnotetext{
${ }^{17}$ Syahrizal Abbas, Mediasi, 59-65.

${ }^{18}$ Syahrizal Abbas, Mediasi, 62.
} 
Sri Wahyuni Husain

Peran mediator ini hanya mungkin diwujudkan bila ia memiliki sejumlah keahlian (skill). Keahlian ini diperoleh melalui sejumlah pendidikan, pelatihan dan sejumlah pengalaman dalam menyelesaikan konflik atau sengketa. Mediator yang memiliki pengalaman banyak akan mudah dirinya menjalankan proses mediasi karena ia sudah terbiasa menghadapi situasi konflik dimana kedua belapihak bertikai. Keterampilan dan pengalaman matang mediator akan terus menerus mendorong dirinya melakukan tindakan-tindakan positif dalam proses mediasi. ${ }^{19}$

\section{Keterampilan Mediator}

Unsur paling penting bagi seseorang mediator adalah keterampilan untuk melakukan mediasi. Skill akan menentukan berhasil tidaknya seorang mediator menyelesaikan sengketa para pihak. Pengetahuan yang banyak belum tentu menjamin keberhasilan mediator dalam pelaksanakan mediasi, tanpa dibarengi dengan sejumlah keterampilan. Keterampilan dapat diperoleh melalui pendidikan dan pelatihan mediasi. Sejumlah keterampilan yang dapat dipakai mediator untuk menyelesaikan sejumlah persengketaan yaitu:

a. Keterampilan Mendengarkan

Keterampilan mendengarkan sangat penting bagi mediator, karena para pihak yang bersengketa ingin didengarkan dan dipahami masalah mereka oleh mediator. Para pihak merasa dihargai bila persoalan mereka didalami secara 'arif oleh mediator.

Kemampuan mendengar ini akan memunculkan kepercayaan dari para pihak bahwa mediator benar-benar memahami dan mendalami persoalan mereka. Mediator akan diterima sebagai juru damai, karena mampu menunjukkan keseriusan dan kemampuannya memahami para pihak. Diterimanya mediator oleh para pihak akan memudahkannya membangun kekuasaan sebagai mediator. Kekuasaan ini bukan untuk mendominasi dan menekan para pihak guna menerima tawaran solusi, tetapi menciptakan ruang yang aman dalam membangun komunikasi konstruktif.

b. Keterampilan Membangun Rasa Memiliki Bersama

Keterampilan membangun rasa memiliki bersama dimulai dengan sikap empati yang ditunjukan mediator terhadap persoalan yang dihadapi para pihak. Mediator harus mengetahui, mengidentifikasi dan memahami

\footnotetext{
${ }^{19}$ Syahrizal Abbas, Mediasi, 80.
} 


\section{Optimalisasi Mediasi di Pengadilan Agama Gorontalo}

perasaan yang dialami oleh pihak yang bersengketa. Mediator menumbuhkan rasa memiliki bersama dengan para pihak, guna merumuskan berbagai solusi atas berbagai persoalan mereka. Caranya sangat tergantung dari kebiasaan dan kultur yang melengkapi para pihak.

c. Keterampilan Memecahkan Masalah

Keterampilan memecahkan masalah adalah keterampilan yang paling esensial dalam proses mediasi, karena inti mediasi adalah menyelesaikan persengketaan yang terjadi antara pihak.

d. Keterampilan Meredam Ketegangan

Mediator dapat mengambil sejumlah tindakan yang merupakan keterampilan dalam mengelola dan meredam kemarahan dari kedua belah pihak yang bersengketa. Mediator harus memposisikan diri sebgai penengah dan tempat para pihak menumpuhkan kemarahannya. Mediator mencegah agar pengungkapan kemarahan tidak secara langsung ditujukan kepada masing-masing pihak. Sebab hal ini dapat menimbulkan konflik yang baru serta memicu memuncaknya emosi para pihak.

e. Keterampilan Merumuskan Kesepakatan

Bila para pihak telah mencapai kesepakatan terhadap sejumlah persoalan yang dipersengketakan, maka mediator perlu merumuskan kesepakatan tersebut dalam bentuk tertulis, maka mediator merumuskan kesepakatan tersebut dalam bentuk tertulis. Dalam perumusan kesepakatan mediator mengajak para pihak secara bersama-sama memberikan tanggapan, apakah kesepakatan tersebut sudah sesuai dengan pembicaraan yang telah berlagsung apakah sudah mencakup hal yang esensial ataukah mereka bersedia untuk melaksanakannya. ${ }^{20}$

Berdasarkan analisa penulis, PERMA Nomor 1 Tahun 2016 tentang Prosedur Mediasi di Pengadilan memiliki kekuatan hukum yang mengikat dan memiliki daya paksa bagi masyarakat. Oleh karena itu, penulis memberikan kesimpulan sebagai berikut:

a. PERMA tidak termasuk dalam hierarki peraturan perundang-undangan sebagaimana tercantum dalam Undang-Undang Nomor 10 Tahun 2004 tentang Pembentukan Peraturan Perundang-undangaan.

\footnotetext{
${ }^{20}$ Syahrizal Abbas, Mediasi, 90.
} 
Sri Wahyuni Husain

b. Jenis peraturan perundang-undangan yang disebutkan dalam Pasal 7 ayat (1) undang-undang tersebut tidaklah bersifat final dan limitatif, karena terdapat jenis peraturan perundang-undangaan lain yang diakui keberadaanya dan mempunyai kekuatan hukum mengikat sepanjang diperintahkan oleh peraturan perundang-undangan yang lebih tinggi.

c. Landasan yuridis PERMA Nomor 1 Tahun 2016 adalah peraturan perundang-undangan, sehingga diakui keberadaannya dan mempunyai kekuatan hukum mengikat. PERMA merupakan pelengkap peraturan perundang-undangan yang telah ada, sehingga bertujuan mengisi kekosongan.

d. Mahkamah Agung memiliki kewenangan dalam membuat peraturan sebagaimana diatur dalam Undang-Undang Nomor 3 Tahun 2009. Oleh karena itu, penerbitan PERMA tidak bertentangan dengan hukum dan aturan perundang-undangaan.

4. Kualifikasi Mediator

Mediator memiliki peran yang sangat penting akan keberhasilan mediasi. Oleh karena itu, mediator harus memiliki kemampuan yang baik agar proses mediasi dapat berjalan lancar dan sesuai dengan prosedur yang telah diatur dalam PERMA Nomor 1 Tahun 2016 tentang Prosedur Mediasi di Pengadilan.

Pasal 13 PERMA Nomor 1 Tahun 2016 pada Bab III Mediator mengatur tentang sertifikasi mediator dan akreditasi lembaga sebagai berikut:

(1) Setiap Mediator wajib memiliki Sertifikat Mediator yang diperoleh setelah mengikuti dan dinyatakan lulus dalam pelatihan sertifikasi Mediator yang diselenggarakan oleh Mahkamah Agung atau lembaga yang telah memperoleh akreditas dari Mahkamah Agung.

(2) Berdasarkan surat keputusan ketua Pengadilan, Hakim tidak bersertifikat dapat menjalankan fungsi Mediator dalam hal tidak ada atau terdapat keterbatasan jumlah Mediator bersertifikat.

(3) Ketentuan lebih lanjut mengenai syarat dan tata cara sertifikasi Mediator dan pemberian akreditasi lembaga sertifikasi Mediator ditetapkan dengan Keputusan Ketua Mahkamah Agung. ${ }^{21}$

\footnotetext{
${ }^{21}$ Mahkamah Agung RI, Peraturan Mahkamah Agung Nomor 01 Tahun 2016
} tentang Proses Mediasi di Pengadilan, pasal 13. 
Oleh karena belum adanya hakim yang memiliki sertifikasi mediator di Pengadilan Agama Gorontalo, sedangkan kebutuhan akan mediator sangat mendesak, maka ada beberapa hakim yang ditetapkan menjadi mediator oleh Ketua Pengadilan Agama Gorontalo. berikut ini:

Hal ini terungkap dari wawancara penulis dengan para informan

Para hakim mediator yang tidak memiliki sertifikat mediator dikarenakan belum mengikuti pelatihan yang diselenggarakan oleh Mahkamah Agung RI. Pelatihan mediator sangat terbatas jumlahnya, karena diselenggarakan Mahkamah Agung RI secara nasional, sehingga pesertanya terbatas dan anggaran yang minim dari Makamah Agung. ${ }^{22}$

Idealnya Mahkamah Agung RI perlu memberikan pelatihan mediator kepada seluruh hakim di pengadilan agama, agar:

a) Para hakim mediator bisa bekerja maksimal sewaktu melakukan mediasi. ${ }^{23}$ Bila telah mendapatkan pelatihan, mereka telah memiliki kemampuan yang sesuai dengan fungsi dan peran sebagai mediator.

b) Mediasi berjalan efektif. ${ }^{24}$ Mediator yang telah terlatih akan mampu mengorganisir proses mediasi dengan baik.

c) Menambah bakat dan keterampilan hakim dalam melakukan mediasi. ${ }^{25}$ Mereka akan memiliki teknik-teknik khusus yang terprogram. ${ }^{26}$ Tugas mediator berbeda dengan hakim saat di persidangan. Bila di persidangan hakim sangat menjaga wibawa pengadilan, sedangkan pada saat menjadi mediator ia harus lebih lembut dan komunikatif, karena berfungsi sebagai penegah konflik antara para pihak yang berperkara.

${ }^{22}$ Wawancara dengan Moh. Hafizh Bula dan Tomi Asram, Hakim Mediator Pengadilan Agama Gorontalo, tanggal 13 April 2017 dan Khoiriah Ahmad, Hakim Pengadilan Agama Gorontalo, tanggal 17 April 2017.

${ }^{23}$ Wawancara dengan Tomi Asaram, Hakim Mediator Pengadilan Agama Gorontalo, tanggal 13 April 2017 dan Khoiriah Ahmad, Hakim Pengadilan Agama Gorontalo, tanggal 17 April 2017.

${ }^{24}$ Wawancara dengan Hatidja Pakaya, Panitera Muda Gugatan Pengadilan Agama Gorontalo, tanggal 17 April 2017.

${ }^{25}$ Wawancara dengan Hasnia, Hakim Pengadilan Agama Gorontalo dan Medang, Hakim Mediator Pengadilan Agama Gorontalo, tanggal 17 April 2017.

${ }^{26}$ Wawancara dengan Tomi Asram, Hakim Mediator Pengadilan Agama Gorontalo, tanggal 13 April 2017. 
Sri Wahyuni Husain

d) Lebih siap saat ditunjuk mediator. ${ }^{27}$ kenyataanya seluruh hakim yang ditetapkan oleh Ketua Pengadilan menjadi mediator, dikarenakan jumlah hakim yang bersertifikat tidak ada dan para hakim yang ditunjuk menjadi mediator memiliki kemampuan untuk menjadi mediator.

\section{Fasilitas dan sarana}

Ruang mediasi di Pengadilan Agama Gorontalo hanya ada 1 (satu) ruang yang didalamnya disediakan 1 (satu) buah meja rapat panjang dan 8 (delapan) buah kursi. Dalam ruangan tersebut dilakukan 1 (satu) kali proses mediasi.

Fasilitas ruang mediasi masih kurang ideal bagi proses mediasi. Faktor-faktor yang menyababkan tidak idealnya ruang mediasi adalah:

a) Ruangan yang tersedia hanya 1 (satu), tidak sebanding dengan jumlah orang yang akan melakukan mediasi. Para pihak seringkali terlihat mengantri sampai hakim mediator melakukan mediasi di ruangan hakim yang tempatnya tidak begitu efisien. ${ }^{28}$

b) Tidak tersedianya ruang untuk kaukus. ${ }^{29}$ Padalah proses kaukus adalah sebagai alternatif yang dapat diupayakan oleh mediator untuk proses perdamaian para pihak.

c) Fasilitas pendukung yang kurang seperti ketersediaan air minum. ${ }^{30}$

Namun walaupun demikian, ruang mediasi di Pengadilan Agama Gorontalo menggunankan Air Conditioner (AC) yang menjadikan ruangan tersebut sejuk dan nyaman. Pengadilan Agama Gorontalo terus berbenah diri untuk memperbaiki dan menambah fasilitas dan sarana ruang mediasi. Selain itu, perawatan terhadap fasilitas dan sarana tetap dilakukan dengan baik dengan dilakukan evaluasi setiap bulannya.

\footnotetext{
${ }^{27}$ Wawancara dengan Tomi Asram, Hakim Mediator Pengadilan Agama Gorontalo, tanggal 13 April 2017.

${ }^{28}$ Wawancara dengan Hasnia, Hakim Pengadilan Agama Gorontalo, tanggal 17 April 2017.

${ }^{29}$ Wawancara dengan Medang, Hakim Mediator Pengadilan Agama Gorontalo, tanggal 17 April 2017.

${ }^{30}$ Wawancara dengan Khoiriah Ahmad, Hakim Pengadilan Agama Gorontalo, tanggal 17 April 2017.
} 
6. Kepatuhan Masyarakat

Bila kita lihat laporan arsip perkara di tahun 2015, dapat diketahui bahwa tingkat keberhasilan mediasi adalah 0,1 \%, kemudian pada tahun 2016 tingkat keberhasilanya sama dengan tahun sebelumnya yaitu $0,1 \%$. Persentase keberhasilannya tidak meningkat dari tahun sebelumnya padahal telah diberlakukannya PERMA Nomor 1 Tahun 2016 atas perubahan PERMA Nomor 1 Tahun 2008 tentang mediasi di Pengadilan Agama.

Penulis melakukan klasifikasi lebih mendetail, dari sejumlah angka mediasi yang akan dapat diketahui angka cerai talak dan cerai gugat. Berikut data yang penulis sajikan.

Pengadilan Agama Gorontalo dalam kurun waktu tahun 2016 telah menerima perkara baik perkara gugatan maupun permohonan dengan Rekapitulasi perkara, yang dapat diuraikan sebagai berikut:

Data di tahun 2016 sebagai berikut:

a) Kepaniteraan Gugatan:

- Menerima perkaa kategori contentius sejumlah 968 perkara.

b) Kepaniteraan Permohonan

- Menerima perkara kategori Voluntair sejumlah 522 perkara.

c) Kepaniteraan Hukum

Tabel 1

Data Penyelesaian Perkara Tahun 2016

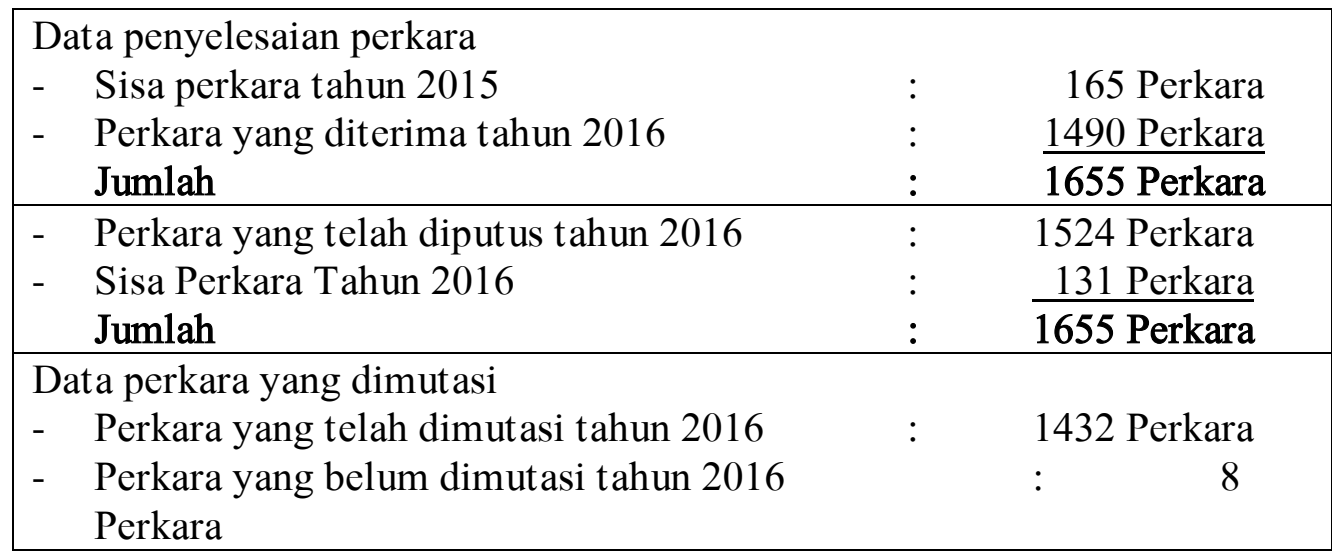

Sumber Data: Laporan Tahunan 2016 Pengadilan Agama Gorontalo 
Sri Wahyuni Husain

Data yang masuk mediasi tahun 2016 sebanyak 84 perkara dan keberhasialan mediasi sebanyak 1 perkara. Ini menunjukkan angka keberhasilan mediasi di tahun 2016 adalah $0,1 \%$ sedangkan angka kegagalan dalam prosedur mediasi adalah 90,9\%.

Setelah mengetahui angka-angka keberhasilan mediasi, penulis memberikan catatan mengenai perilaku dan sikap para pihak selama menjalani proses mediasi yang mempengaruhi kepatuhan dalam menjalani proses mediasi sebagai berikut:

a. Seringkali salah satu pihak atau keduanya merasa paling benar. ${ }^{31}$ Sehingga mediator kesulitan untuk mendalami masalah karena sikap para pihak yang tidak kooperatif selama proses mediasi. Begitupun sikap egois sering muncul diantara para pihak yang mengikuti mediasi.

b. Sebelum para pihak memasuki pemeriksaan perkara di persidangan, banyak dari mereka seringkali sudah bersepakat untuk memutuskan ikatan Perkawinan. $^{32}$ Sehingga pada saat dimediasi mediator mendapatkan kesulitan hingga gagal dalam mendamaikan pihak.

c. Para pihak ada juga yang bersikap koperatif, namun sikap tersebut dilakukan agar proses mediasi cepat selesai sehingga dapat dilanjutkan dengan proses persidangan selanjutnya. Para pihak biasanya mengikuti mediasi hanya sebagai formalitas semata.

\section{E. Kendala-Kendala Penghambat Keberhasilan Mediasi}

Keberhasilan atau kegagalan mediasi sangat dipengaruhi oleh kendala-kendala penghambat selama proses mediasi. Berikut kendalakendala penghambat keberhasilan mediasi:

1. Keinginan Kuat Para Pihak Bercerai

Seringkali terjadi saat mediasi salah satu pihak bahkan keduanya sudah sangat kuat keinginan mereka untuk bercerai. Kedatangan mereka ke Pengadilan Agama biasanya terjadi akibat ketidakberhasilan dari pihak

\footnotetext{
${ }^{31}$ Wawancara dengan Khoiriah Ahmad, Hakim Pengadilan Agama Gorontalo, tanggal 17 April 2017.

${ }^{32}$ Wawancara dengan Medang, Hakim Mediator Pengadilan Agama Gorontalo, tanggal 17 April 2017.
} 
keluarga untuk mendamaikan, sehingga hal ini yang sering menyulitkan mediator untuk mengupayakan perdamaian. ${ }^{33}$

2. Terjadi Konflik yang Berkepanjangan

Konflik atau percekcokan yang terjadi diantara para pihak sudah berlarut-larut, dan saat mediasi para pihak tidak lagi dapat diredam emosinya. Sehingga para pihak tidak dapat menerima lagi masukan-masukan serta nasehat-nasehat dari mediator dan merasa dirinya benar.

Bahkan sering terjadi salah satu pihak entah Pemohon/Penggugat ataupun Termohon/Tergugat sudah tidak bisa lagi memaafkan satu sama lain sehingga sulit untuk berdamai kembali. ${ }^{34}$

3. Faktor Psikologi/Kejiwaan

Kekecewaan yang sangat dalam diantara para pihak yang berperkara seringkali memunculkan rasa putus asa serta harapan seseorang akan ikatan perkawinannya. Sehingga tidak ada pilihan lain kecuali mengakhiri perkawinan yang sudah mereka jalin bersama. ${ }^{35}$

\section{Ketiadaan Kakim Mediator yang Bersertifikat}

Kurangnya hakim yang belum bersertifikat mengakibatkan proses mediasi tidak berjalan dengan baik, dikarenakan apabila ada hakim yang sudah memiliki sertifikan diyakini memiliki kemampuan lebih dalam memediasi suatu perkara. ${ }^{36}$

\section{Ruangan Mediasi dan Ruangan Kaukus Belum Maksimal}

Wawancara dengan hakim Khoriah Ahmad mengemukakan bahwa kurangnya ruangan mediasi membuat para pihak mengantri untuk melakukan mediasi sehingganya para pihak yang berperkara melakukan mediasi di ruangan para hakim mediator itu sendiri, menjadikan proses

${ }^{33}$ Wawancara dengan Hasnia HD, Hakim Pengadilan Agama Gorontalo, tanggal 17 April 2017 dan Yitsanti Laraga, Panitera Muda Hukum Pengadilan Agama Gorontalo, tanggal 13 April 2017. April 2017.

${ }^{34}$ Wawancara dengan Hasnia HD, Hakim Pengadilan Agama Gorontalo, tanggal 17

${ }^{35}$ Wawancara dengan Khoiriah Ahmad Hakim Pengadilan Agama Gorontalo, tanggal 17 April 2017 dan Hatidjah Pakaya, Panitera Muda Gugatan Pengadilan Agama Gorontalo, tanggal 17 April 2017.

${ }^{36}$ Wawancara dengan Tomi Asram Hakim Mediator Pengadilan Agama Gorontalo, tanggal 13 April 2017. 
Sri Wahyuni Husain

mediasi tidak berjalan lancar. ${ }^{37}$ Juga tidak adanya ruangan kaukus membuat para pihak yang berperkara tidak dapat menyampaikan beberapa hal pribadi kepada hakim mediator. 38

6. Keterbatasan Mediator

Dari begitu banyaknya perkara yang masuk ke Pengadilan Agama Gorontalo sedangkan jumlah Hakim terbatas dan tidak adanya Mediator dari luar (Pengadilan Agama Gorontalo tidak mempunyai daftar Mediator non Hakim) sehingga proses mediasi ini menambah pekerjaan para Hakim, hal ini lah yang menyebabkan pekerjaan Hakim Mediator kurang maksimal. Biasanya sidang dalam sehari itu dua Majelis, maka secara otomatis ada salah satu atau dua orang yang mendapat jatah untuk mediasi hari itu, ditambah lagi selain membantu mediasi Ketua Majelis dan anggotanya juga mempunyai tanggungjawab untuk menangani perkara yang banyak, hal tersebut menjadi salah satu kendalanya.

7. Tidak Hadirnya Salah Satu Pihak

Kehadiran para pihak yang berperkara sangatlah penting, seringkali para pihak tidak hadir dalam proses mediasi walaupun mereka telah dipanggil secara patut dan berturut-turut.

\section{Kurangnya Pemahaman Para Pihak tentang Mediasi}

Ketidaktahuan para pihak tentang proses mediasi. Bagi mereka mediasi adalah menyelesaikan masalah, yang penting dalam prosesnya terdapat pembicaraan (musyawarah), tidak peduli apakah dalam pembicaraan itu berat sebelah atau tidak. Biasanyapara pihaktidak kooperatif untuk diajak mediasi karena sudah terjadi perselisihan yang berkepanjangan lalu pengadilan menjadi puncak akhir dari permasalahan mereka, mereka mengikuti proses mediasi bukan karena keinginan hati, bukan karena mereka melihat ada peluang yang baik dari mediasi atau mereka melihat keuntungan dari mediasi. Tetapi karena kekhawatiran putusan mereka akan batal demi hukum apabila tidak mengikuti proses mediasi sebelumnya.

\footnotetext{
${ }^{37}$ Wawancara dengan Khoiriah Ahmad Hakim Pengadilan Agama Gorontalo, tanggal 17 April 2017.

${ }^{38}$ Wawancara dengan Medang Hakim Mediator Pengadilan Agama Gorontalo, tanggal 17 April 2017.
} 


\section{F. Penutup}

Pengoptimalan pelaksanaan mediasi di Pengadilan Agama Gorontalo analisis PERMA Nomor 1 Tahun 2016 tentang Prosedur Mediasi di Pengadilan belumlah bisa dikatakan optimal keseluruhannya, dikarenakan belum ada mediator yang memiliki sertifikat ataupun mengikuti pelatihan mediasi yang mana seperti diatur dalam PERMA tersebut, serta kualitas hakim yang ditunjuk sebagai mediator belum merata dan dilihat dari banyaknya kegagalan mediasi yang dimediasi oleh mediator di Pengadilan Agama Gorontalo, sehingga mengakibatkan pelaksanaan mediasi di Pengadilan Agama Gorontalo belum optimal secara keseluruhan.

Kendala penghambat yang dihadapi dalam pelaksanaan mediasi di Pengadilan Agama berupa: keinginan kuat para pihak untuk bercerai, sering sekali salah satu pihak atau keduanya merasa paling benar; sudah terjadi konflik yang berkepanjangan diantara pihak, sehingganya sulit bagi mediator untuk mendamaikan para pihak; faktor psikologi atupun kejiwaan, disini juga menyebabkan salah satu pihak enggan untuk berdamai lagi; tidak adanya hakim mediator yang telah bersertifikat, mengakibatkan prosedur mediasi kurang efektif dalam pelaksanaanya; kurangnya sarana penunjang berupa ruangan mediasi dan ruangan kaukus, berimbas pada antrian yang panjang diantara para pihak yang berperkara untuk melaksanakan mediasi; keterbatasan mediator, minimnya jumlah mediator di pengadilan agama gorontalo dan tidak adanya mediator dari non hakim; tidak hadirnya salah satu pihak, menyebabkan proses mediasi tidak berjalan dengan lancar; kurangnya pemahaman bagi para pihak tentang pentingnya mediasi, sehingga banyak dari para pihak yang tidak mengetahui dan tidak datang pada saat pemanggilan untuk mediasi.

\section{Daftar Pustaka}

Abbas, Syahrizal. Mediasi dalam Perspektif Hukum Syariah, Hukum Adat, dan Hukum Nasional. Cet. I; Jakarta: Kencana Prenada Media, 2009.

Emirzon, Joni. Alternatif Penyelesaian Sengketa di Luar Pengadilan. Jakarta: Gramedia Pustaka Utama, 2001.

Fuady, Munir. Arbitras Nasional, Alternatif Penyelesaian Sengketa Bisnis. Bandung: Citra Aditya Bakti, 2004. 
Sri Wahyuni Husain

Harahap, M. Yahya. Hukum Acara Perdata: Tentang Gugatan, Persidangan, Penyitaan, Pembuktian, dan Putusan Pengadilan. Cet. VII; Jakarta: Sinar Grafika, 2008.

Mahkamah Agung RI. Peraturan Mahkamah Agung Nomor 01 Tahun 2016 tentang Proses Mediasi di Pengadilan.

Republik Indonesia, Undang-Undang Dasar RI Tahun 1945.

Susanti Adi Nugroho, Mediasi Sebagai Alternatif Penyelesaian Sengketa. Cet. I; Jakarta: Telaga Ilmu, 2009.

Tresna, R. Komentar HIR. Cet. XVIII; Jakarta: Pradnya Paramita, 2005. 